\title{
Deactivation of Fe-N-C catalysts during catalyst ink preparation process
}

\author{
Gajeon Chon $^{\mathrm{a} 1}$, Minhee Suk ${ }^{\mathrm{a} 1}$, Frédéric Jaouen ${ }^{\mathrm{b}}$, Min Wook Chung ${ }^{\mathrm{a} *}$ and Chang Hyuck \\ $\mathrm{Choi}^{\mathrm{a} *}$
}

${ }^{a}$ School of Materials Science and Engineering, Gwangju Institute of Science and Technology, Gwangju 61005, Republic of Korea.

${ }^{b}$ Institut Charles Gerhardt Montpellier, UMR CNRS 5253, Agrégats, Interfaces et Matériaux pour l'Energie, Université de Montpellier, 34095 Montpellier Cedex 5, France.

${ }^{1}$ These authors contributed equally to this work.

*Correspondence to: M.W. Chung (cmw21sky@gist.ac.kr), C.H. Choi (chchoi@gist.ac.kr)

\begin{abstract}
The membrane electrode assembly (MEA) is a core component of low-temperature fuel cells. The first step of MEA manufacturing is the preparation of a catalyst ink suspension in which the catalyst powder is homogeneously dispersed in a liquid solvent through mechanical or sonic agitation. In this work, we have studied the effects of catalyst dispersion in water or alcohol solutions and subsequent drying processes on the physicochemical properties of Fe$\mathrm{N}-\mathrm{C}$ catalysts and their electrocatalytic oxygen reduction activities. We find that dispersing the model Fe-N-C catalyst comprising only $\mathrm{FeN}_{\mathrm{x}} \mathrm{C}_{\mathrm{y}}$ moieties in water and subsequent drying treatment change neither its bulk structure nor surface composition, as indicated by various spectroscopic measurements before and after treatment. However, zeta potential measurements, which are very sensitive to the chemistry of functionalities present on the carbon surface, reveal that the Fe-N-C catalyst becomes slightly more acidic, and that the change in their acido-basicity is magnified with a) increasing treatment temperature and b) repetitions of a same wetting/drying treatment. This small change in the surface acidobasicity of the Fe-N-C catalyst results in a measurable and reproducible decrease in its electrocatalytic activity, which shows a positive correlation with the zeta potential changes measured at $\mathrm{pH}=1$. Observed on the Fe-N-C catalyst but not on $\mathrm{Pt} / \mathrm{C}$, it is surmised that the electrocatalytic activities of the oxygen-reducing $\mathrm{FeN}_{\mathrm{x}} \mathrm{C}_{\mathrm{y}}$ moieties are influenced by the surface chemistry of the carbonaceous support. Since catalyst wetting and drying processes are essential for MEA fabrication for fuel cells, these results suggest that careful attention
\end{abstract}


should be paid to the conditions employed to prepare and dry catalytic inks for the family of Fe-N-C catalysts in order to obtain their highest possible ORR activity.

Keywords: Oxygen reduction reaction; Non-precious metal catalysts; Proton-exchange membrane fuel cells; Fe-N-C catalysts; Ink preparation; Sonication 


\section{Introduction}

Proton-exchange membrane fuel cells (PEMFCs) are electrochemical devices that convert the chemical energy of an externally supplied fuel (e.g., hydrogen) directly into electricity. Due to their high energy efficiency and specific power density at low operating temperatures $\left(c a .<80^{\circ} \mathrm{C}\right.$ ), PEMFCs have rapidly been adopted for stationary and automotive applications $[1,2]$. The core of the PEMFC system is the MEA, which consists of a proton-exchange membrane, catalyst layers and gas diffusion layers (GDLs). High proton and/or electron conductivity in the membrane and catalyst layers, easy transport of the gas into the catalyst layers and effective water management (e.g., for sufficient membrane hydration while avoiding catalyst layer flooding) are prerequisites for achieving high PEMFC performance [3-5]. Hence, many studies have focused on MEA fabrication processes in order to maximize PEMFC performance [6-8].

In general, the membrane and GDL components of the MEA are fabricated separately, and then assembled in a single MEA using hot-pressing methods $[9,10]$. The catalyst layers are usually either fabricated directly on the membrane via spray or painting methods (Catalystcoated membrane, CCM) or on rigid support such as the GDL itself (catalyst coated layer, CCL) or a polymer sheet. In the latter case, the catalyst layer is then subsequently transferred onto the membrane via a decal transfer [11-13]. Regardless of the particular method employed to fabricate the catalyst layer, the manufacturing begins with the preparation of an ink which is a suspension containing the catalyst powder, an ionomer and liquid solvents (e.g., water, ethanol, isopropyl alcohol, etc.). The quality of the ink suspension is of great importance for the quality of the final catalyst layers in the MEA. Dispersion of aggregated catalyst particles and of ionomer is typically achieved by a long-time wetting of the powder with the solvents under external powers of mechanical stirring or, more commonly, sonication (e.g., ultrasonic bath or tip-probe).

The principle of sonication leans on sound energy with an ultrasonic frequency higher than $20 \mathrm{kHz}$. As the frequency increases, the agitation of particles is intensified. However, the ultrasonic sound concurrently induces local temperature increase in the medium due to vibration and acoustic cavitation [14-18]. Consequently, sonication can also overcome energy barriers for chemical bond formation and cleavage [19-22]. Mild oxidation of carbon surfaces after sonication has for instance been repeatedly reported $[23,24]$. In spite of its potential to 
chemically modify substances, sonication (or mechanical stirring) processes have frequently been used to homogenize catalyst inks, without serious consideration of possible modifications to the surface chemistry of the catalysts during the energetic treatment.

In this study, we characterized changes in the surface chemistry of a model Fe-N-C catalyst (comprising $\mathrm{Fe}$ solely as $\mathrm{FeN}_{\mathrm{x}} \mathrm{C}_{\mathrm{y}}$ moieties) before and after its dispersion in water in a temperature range of $25-75^{\circ} \mathrm{C}$ and by means of either a) sonication or b) mechanical stirring. $\mathrm{Fe}$ (or $\mathrm{Co}$ )-N-C catalysts, in which $\mathrm{Me}-\mathrm{N}_{\mathrm{x}}$ active moieties are imbedded in a carbonaceous support, are a promising class of non-precious metal catalysts (NPMCs), with prospects to replace $\mathrm{Pt} / \mathrm{C}$ catalysts for oxygen reduction reaction (ORR) at the cathode of PEMFCs [2540]. We find that both the sonication and stirring treatments induced subtle chemical modifications of the carbonaceous supports in the Fe-N-C catalyst, which led to a nonnegligible decay of its electrocatalytic activity (from $c a$. -15 to $-65 \%$ @ $0.8 \mathrm{~V}_{\mathrm{RHE}}$ ) in acidic medium. The extent of surface modification increased with increasing temperature, duration and number of repetition of the treatments. Since these modifications were observed on the model Fe-N-C catalyst and also on a commercial Fe-N-C catalyst (comprising both $\mathrm{FeN}_{\mathrm{x}} \mathrm{C}_{\mathrm{y}}$ moieties and Fe particles) but not on a benchmark Pt/C catalyst, careful attention should be paid to the preparation of MEAs with cathodes based on Fe-N-C.

\section{Experimental methods}

\subsection{Catalyst synthesis and wetting procedures}

In order to explore the effect of wetting and dispersion conditions on the structure and activity of Fe-N-C catalysts, we selected Fe-N-C catalyst that is composed solely of organometallic single-metal-atom $\mathrm{FeN}_{\mathrm{x}} \mathrm{C}_{\mathrm{y}}$ moieties and without detectable content of $\mathrm{Fe}$ aggregates (e.g., metallic Fe, carbide, oxide, etc.). This catalyst, prepared by us, has been characterized in several previous studies exploring various deactivation and degradation mechanisms of Fe-N-C catalysts [41-44]. It was synthesized by the pyrolysis of $\mathrm{Fe}^{\mathrm{II}}$ acetate, 1,10-phenanthroline (phen) and a zeolite imidazolate framework (ZIF-8, Basolite Z1200 from Sigma). The catalyst precursor $(1 \mathrm{~g})$, which contained Fe/phen/ZIF-8 in a mass ratio of 0.5/20/80, was ball-milled in a $\mathrm{ZrO}_{2}$ crucible with $100 \mathrm{ZrO}_{2}$ balls (5 mm diameter) in a planetary ball-miller for four cycles of $30 \mathrm{~min}$ each at a rotation rate of $400 \mathrm{rpm}$. The homogenized powder was then pyrolyzed at $1050{ }^{\circ} \mathrm{C}$ for $1 \mathrm{~h}$ under an $\mathrm{Ar}$ atmosphere. The catalyst is henceforth labelled ' $\mathrm{Fe}_{0.5}-\mathrm{NC}$ '. Selected experiments were also performed on 
commercially available Pt/C (46 wt\%, TEC10E50E, Tanaka) and Fe-N-C catalysts (Pajarito Powder; labelled ' $\mathrm{Fe}-\mathrm{N}-\mathrm{C}_{\mathrm{PP}}$ '). The general synthetic approach of the latter catalyst is via silica-templating. A mesoporous silica powder is infiltrated with $\mathrm{Fe}, \mathrm{N}$ and $\mathrm{C}$ precursors, pyrolyzed in inert gas and the silica template is then removed by acid treatment. This Fe-N-C catalyst comprises both $\mathrm{FeN}_{\mathrm{x}} \mathrm{C}_{\mathrm{y}}$ moieties and $\mathrm{Fe}$ aggregates (e.g., metallic $\mathrm{Fe}$, carbide, etc.; Fig. S1).

Deionized (DI) water was selected as the wetting solvent since it is present in most ink suspensions used for preparing catalyst inks for PEMFC MEAs. For the wetting treatment, the Fe-N-C catalyst $(30 \mathrm{mg})$ was added to DI water $\left(100 \mathrm{~mL}\right.$, Arium ${ }^{\circledR}$ mini Water System, Sartorius), and dispersed by only sonication or only mechanical agitation, at a fixed temperature. The range of temperature from 25 to $75{ }^{\circ} \mathrm{C}$ was explored. Sonication was carried out at an ultrasonic frequency of $40 \mathrm{kHz}$ in an ultrasonic bath (UCP-10, Jeio Tech) with catalyst-containing solvent placed in a round bottom flask of $250 \mathrm{~mL}$. Mechanical agitation was performed at a rotation speed of 1,000 rpm using a magnetic stirrer (diameter $=8 \mathrm{~mm}$, length $=25 \mathrm{~mm}$ ). After the treatment, the wetted catalyst was first dried in a forced convection oven (OF-12GW, Jeio Tech) at $70{ }^{\circ} \mathrm{C}$ for $3 \mathrm{~h}$ and then in a vacuum oven (OV-11, Jeio Tech) at $70{ }^{\circ} \mathrm{C}$ overnight. When the catalyst was wetted several times, the same number of drying step was followed after each wetting treatment. Depending on the conditions applied during the treatment, the samples are referred to as ' $S_{x}(y h-z)$ ' or ' $M_{x}(y h-z)$ ', where $S$ and $\mathrm{M}$ denote sonication and mechanical agitation treatment, respectively. The $\mathrm{x}, \mathrm{y}$ and $\mathrm{z}$ scalars correspond to the temperature (in ${ }^{\circ} \mathrm{C}$ ) during treatment, duration (in hour) and number of the treatments, respectively. To maintain the temperature of the ultrasonic bath close to room temperature, cooling tap-water $\left(25^{\circ} \mathrm{C}\right)$ was continuously flowed through a copper tube heat exchanger in the bath, resulting after 10 minutes of sonication in a steady-state temperature of $29^{\circ} \mathrm{C}$ (Fig. S2). To raise the temperature to a specific temperature between 35 and $75{ }^{\circ} \mathrm{C}$ during mechanical stirring, the catalyst suspension was heated by a heating mantle equipped with a reflux condenser to prevent liquid evaporation.

\subsection{Electrochemical characterization}

The electrochemical results were obtained using a modulated speed rotator (RRDE-3A, ALS) in a Teflon cell with a three-electrode system consisting of a graphite rod as the counter electrode and a saturated $\mathrm{Ag} / \mathrm{AgCl}$ reference electrode (RE-1A, EC-Frontier). The electrolyte 
was $0.1 \mathrm{M} \mathrm{HClO}_{4}$, which was prepared from concentrated $\mathrm{HClO}_{4}(70 \%$, Aldrich). Prior to any electrochemical measurements, the $\mathrm{Ag} / \mathrm{AgCl}$ reference electrode was calibrated against a Pt electrode immersed in $\mathrm{H}_{2}$-saturated $0.1 \mathrm{M} \mathrm{HClO}_{4}$ electrolyte, acting as a reversible hydrogen electrode (RHE). For Fe-N-C catalysts $\left(\mathrm{Fe}_{0.5}-\mathrm{NC}\right.$ and $\left.\mathrm{Fe}-\mathrm{N}-\mathrm{C}_{\mathrm{PP}}\right)$, the inks based on pristine or previously treated catalyst (sonication or mechanical agitation, as described in section 2.1) were prepared by dispersing $10 \mathrm{mg}$ of catalyst in $804 \mu \mathrm{L}$ of water and $80 \mu \mathrm{L}$ of 5 wt\% Nafion solution. Regardless of the catalyst nature, the ink suspension was then sonicated for $1 \mathrm{~h}$ in the ultrasonic bath at $29^{\circ} \mathrm{C}$. Working electrodes were prepared by pipetting $5 \mu \mathrm{L}$ of the catalyst ink onto the glassy carbon disk $\left(0.071 \mathrm{~cm}^{2}\right)$ of the rotating disk electrode $(011169$, ALS), resulting in a catalyst loading of $800 \mu \mathrm{g} \mathrm{cm}^{-2}$ for $\mathrm{Fe}-\mathrm{N}-\mathrm{C}$ materials. For the $\mathrm{Pt} / \mathrm{C}$ catalyst, Pt loading on the working electrode was set to $20 \mu \mathrm{g}_{\mathrm{Pt}} \mathrm{cm}^{-2}$. The catalyst loaded electrode was dried in a convection oven at $35{ }^{\circ} \mathrm{C}$ for $30 \mathrm{~min}$. The ORR polarization curve was recorded at a $10 \mathrm{mV} \mathrm{s}^{-1}$ scan rate and a $900 \mathrm{rpm}$ rotation speed in an $\mathrm{O}_{2}$-saturated electrolyte. For all catalysts, ORR polarization curve measured at a negative-going scan was selected. To remove the non-Faradaic capacitance current density, polarization curve measured using the same procedure but in an Ar-saturated electrolyte was subtracted from the result. The kinetic current density was estimated using the Koutecky-Levich equation; i.e., $1 / j$ $=1 / j_{\mathrm{k}}-1 / j_{\mathrm{d}}$, where $j_{\mathrm{k}}$ and $j_{\mathrm{d}}$ are the kinetic and diffusion current densities, respectively. Electrochemical reduction of the carbon surface was performed with a $\mathrm{M}_{45}(1 \mathrm{~h}-3)$ sample, which exhibited the highest activity decay among the water-treated samples. Cyclic voltammetry $(\mathrm{CV})$ was applied in a potential range from 0 to $-1.6 \mathrm{~V}_{\mathrm{Ag} / \mathrm{AgCl}}$ for 100 cycles with a scan rate of $100 \mathrm{mV} \mathrm{s}^{-1}$ in an Ar-saturated $0.5 \mathrm{M} \mathrm{NaCl}$ electrolyte [45].

\subsection{Physical characterization}

${ }^{57} \mathrm{Fe}$ Mössbauer spectroscopy was used to characterize various iron species in $\mathrm{Fe}-\mathrm{N}-\mathrm{C}_{\mathrm{PP}}$. The measurements were carried out with a $\gamma$-radiation source of ${ }^{57} \mathrm{Co}-\mathrm{Rh}$ and a $\mathrm{NaI}$ scintillation detector at room temperature. X-ray photoelectron spectroscopy (XPS) was carried out using a K-Alpha (Thermo Scientific) instrument equipped with a micro-focused $\mathrm{Al} \mathrm{K}_{\alpha}$ monochromator X-ray source and a $180^{\circ}$ double-focusing hemispherical analyzer. Xray diffraction (XRD) patterns were acquired using an X'Pert PRO (Malvern Panalytical) with $\mathrm{Cu} \mathrm{K} \mathrm{K}_{\alpha} \mathrm{X}$-ray radiation generated at $40 \mathrm{kV}$ and $40 \mathrm{~mA}$. Raman scattering was detected using a Nicolet Almega XR (Thermo Scientific) equipped with a CCD detector. A $532 \mathrm{~nm}$ laser beam with a $\times 10$ magnification objective was used. The acido-basicity of the catalyst's 
surface was determined by dispersing $40 \mathrm{mg}$ of a catalyst in $30 \mathrm{~mL}$ of a $\mathrm{pH} 6$ aqueous solution $\left(\mathrm{pH}_{\mathrm{i}}\right)$; the $\mathrm{pH}$ was adjusted using a mixture of $0.1 \mathrm{M} \mathrm{H}_{2} \mathrm{SO}_{4}$ and $0.1 \mathrm{M} \mathrm{KOH}$. The solutions were kept saturated with Ar throughout the experiment. The $\mathrm{pH}$ was recorded using a $\mathrm{pH}$ meter, and the final $\mathrm{pH}\left(\mathrm{pH}_{\mathrm{f}}\right)$ was recorded when the $\mathrm{pH}$ value became steady with time. To compare the acido-basicity of the wetted samples relative to the pristine $\mathrm{Fe}-\mathrm{N}-\mathrm{C}$ catalyst, we used the expression $\Delta \mathrm{pH}_{\mathrm{f}}=\mathrm{pH}_{\mathrm{f}}$ (wetted Fe-N-C catalyst $)-\mathrm{pH}_{\mathrm{f}}$ (pristine Fe-N-C catalyst). A negative $\Delta \mathrm{pH}_{\mathrm{f}}$ value would thus indicate more acidic surface after treatment. The zeta potentials of the catalysts were recorded using a Zetasizer Nano ZS (Malvern) with a $4 \mathrm{~mW}$ $633 \mathrm{~nm} \mathrm{He}-\mathrm{Ne}$ laser. Before the measurements, $5 \mathrm{mg}$ of the catalyst was dispersed in a $0.1 \mathrm{M}$ $\mathrm{HClO}_{4}$ solution $(7.5 \mathrm{~mL})$, and the suspensions were then ultra-sonicated to prevent the agglomeration of the catalyst particles. An aliquot $(c a .150 \mu \mathrm{L})$ of the suspension was placed into a glass cell. The zeta potential of each sample was recorded more than six times, and the average value of all the measurements was determined.

\section{Results and discussion}

\subsection{ORR activity of the Fe-N-C catalyst after wetting treatments}

We first investigated the effects of sonication of the Fe-N-C suspension on its ORR activity without using temperature control in the sonication bath (i.e., no heat exchanger tube). This uncontrolled condition, which is typically used in catalyst ink preparation, induced vibrational motion of the water molecules and increased the temperature of the sonication bath to $55^{\circ} \mathrm{C}$ after $3 \mathrm{~h}$ of operation (Fig. S2). Figure 1 shows the ORR polarization curves of $\mathrm{Fe}_{0.5}$-NC before and after $2 \mathrm{~h}$ of sonication in DI water without temperature control. The $j_{\mathrm{k}}$ value measured at $0.8 \mathrm{~V}_{\mathrm{RHE}}$ was $c a .3 .2 \mathrm{~mA} \mathrm{~cm}^{-2}$ for the pristine $\mathrm{Fe}_{0.5}-\mathrm{NC}$, but it decreased to ca. $1.6 \mathrm{~mA} \mathrm{~cm}^{-2}$ after the treatment (Fig. 1a). In spite of this non-negligible drop in the ORR activity, the rate-determining step (RDS) was unchanged after the treatment, as revealed by the similar Tafel slopes of $c a .63-66 \mathrm{mV} \mathrm{dec}^{-1}$ before and after treatment (Fig. 1b). These preliminary results represent that the typical agitation method used in catalyst ink preparation can negatively affect the intrinsic ORR activity of the Fe-N-C catalysts. 

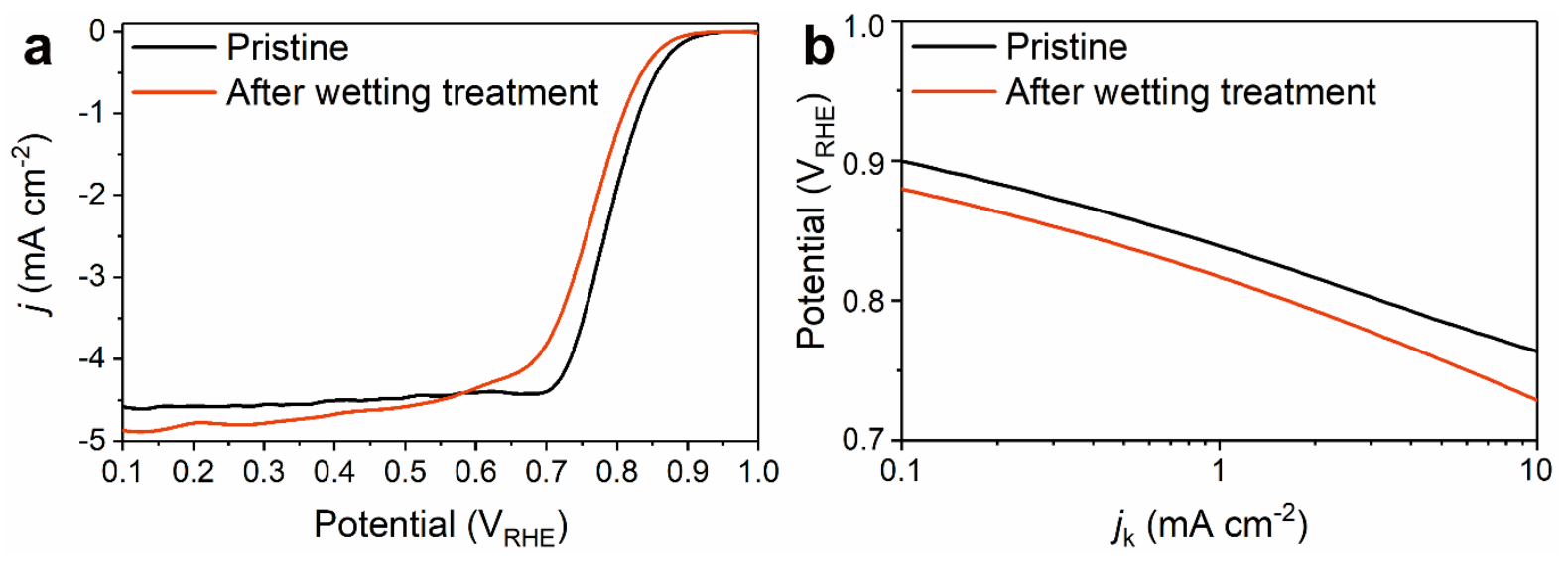

Fig. 1. (a) ORR polarization curves and (b) Tafel plots of the $\mathrm{Fe}_{0.5}-\mathrm{NC}$ before and after $2 \mathrm{~h}$ of sonication in DI water without temperature control. After sonication, the catalyst powder was dried in an oven and re-dispersed to prepare the ink suspension. The electrochemical responses were measured in an $\mathrm{O}_{2}$-saturatred $0.1 \mathrm{M} \mathrm{HClO}_{4}$ electrolyte with a scan rate of 10 $\mathrm{mV} \mathrm{s}^{-1}$ and a rotation speed of $900 \mathrm{rpm}$.

Sonication treatment involves acoustic cavitation, and therefore generates vibration and heat energy. This could possibly lead to the dissociation of water molecules into hydrogen $(\bullet \mathrm{H})$ and hydroxyl radicals $(\bullet \mathrm{OH})[14,46-49]$, which in turn can induce chemical reactions on the Fe-N-C surface. To determine whether the activity decay after the treatment was provoked by radical species or by simple wetting with DI water, the ORR activities of Fe-N$\mathrm{C}$ catalysts treated using either sonication or stirring (i.e., mechanical agitations) in DI water for $1 \mathrm{~h}$ were compared. In both conditions, the suspensions were maintained at a temperature of $29^{\circ} \mathrm{C}$, which was the equilibrium temperature of the sonication bath in the presence of the copper tube heat exchanger (Fig. S2), to exclude incidental thermal effects on the ORR activity. As can be seen in Fig. $2 \mathrm{a}$, the $j_{\mathrm{k}}$ values at $0.8 \mathrm{~V}_{\mathrm{RHE}}$ of the treated $\mathrm{Fe}_{0.5}-\mathrm{NC}$, i.e., $\mathrm{S}_{29}(1 \mathrm{~h}-1)$ and $\mathrm{M}_{29}(1 \mathrm{~h}-1)$, were lower than that of the pristine $\mathrm{Fe}_{0.5}-\mathrm{NC}$ by $c a .1 .2 \mathrm{~mA} \mathrm{~cm}{ }^{-2}$. The decay in their ORR activity was almost identical for both treatment methods. This result indicates that wetting with water and subsequent drying (rather than radical formation) was the primary cause of the ORR activity loss of the Fe-N-C catalysts in these experimental conditions. 

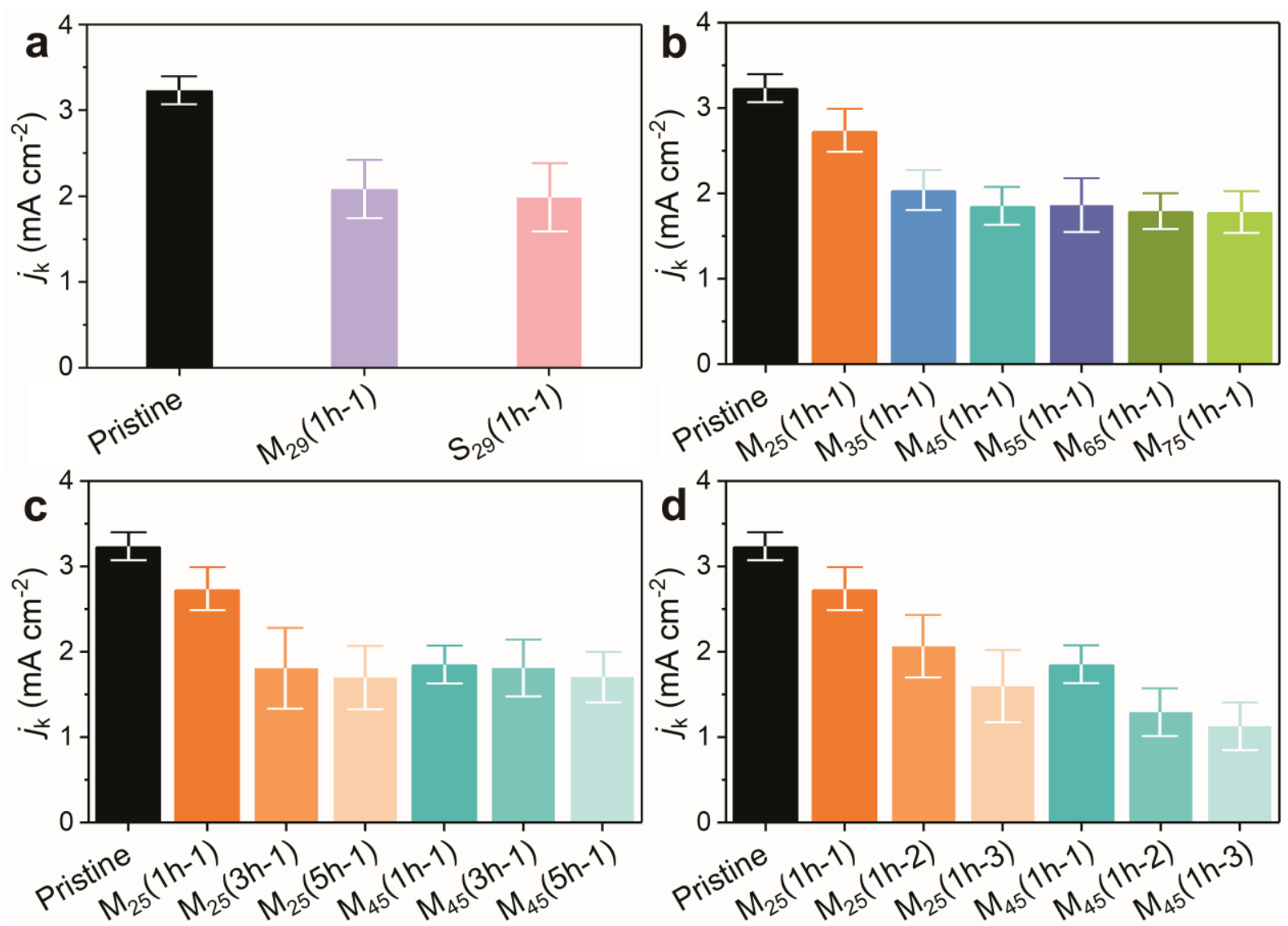

Fig. 2. ORR kinetic current density measured at $0.8 \mathrm{~V}_{\mathrm{RHE}}$ before and after wetting treatment using different conditions for $\mathrm{Fe}_{0.5}$-NC: (a) different wetting methods (mechanical agitation, M vs. sonication, S); mechanical agitation (b) at temperatures from 25 to $75{ }^{\circ} \mathrm{C}$, (c) for different combinations of temperature $\left(25\right.$ or $\left.45^{\circ} \mathrm{C}\right)$ and duration $(1 \mathrm{~h}, 3 \mathrm{~h}$ or $5 \mathrm{~h})$ and (d) for different combinations of temperature $\left(25\right.$ or $\left.45^{\circ} \mathrm{C}\right)$ and numbers of treatments $(1,2$ or 3$)$.

We thus conducted further studies on the effects of wetting and drying on the ORR activity of $\mathrm{Fe}_{0.5}$-NC using mechanical stirring in water (Fig. S3). Fig. 2b shows the changes in the ORR activity after conducting the wetting treatments at various temperatures. The duration of the treatment was set to $1 \mathrm{~h}$. As the temperature was increased, the extent of the decline in the activity $\left(\Delta j_{\mathrm{k}}\right.$ at $\left.0.8 \mathrm{~V}_{\mathrm{RHE}}\right)$ increased by $c a .1 .4 \mathrm{~mA} \mathrm{~cm}^{-2}$; no further activity loss was found for a $1 \mathrm{~h}$ single treatment at temperatures higher than $45^{\circ} \mathrm{C}$. The duration and number of treatments were also found to influence the ORR activity decay of $\mathrm{Fe}_{0.5}-\mathrm{NC}$ (Figs. 2c and d). When the treatment duration and/or the number of treatments increased, the ORR activity of $\mathrm{Fe}_{0.5}$-NC decreased. Other typical solvents for ink preparations (e.g., ethanol and isopropyl 
alcohol) also resulted in performance drops similar to that caused by water (Fig. S4). Furthermore, this deactivation was also observed for the commercial Fe-N-C $\mathrm{C}_{\mathrm{PP}}$ (Fig. S5), that comprises not only $\mathrm{FeN}_{\mathrm{x}}$ moieties but also core-shell $\mathrm{Fe}$ and $\mathrm{Fe}_{3} \mathrm{C}$ particles surrounded by graphene shell (Fig. S1). This deactivation in conditions of ink preparation thus seems to be specific for the Fe-N-C catalysts, and was not observed on commercial carbon-supported Pt nanoparticles (Fig. S5a).
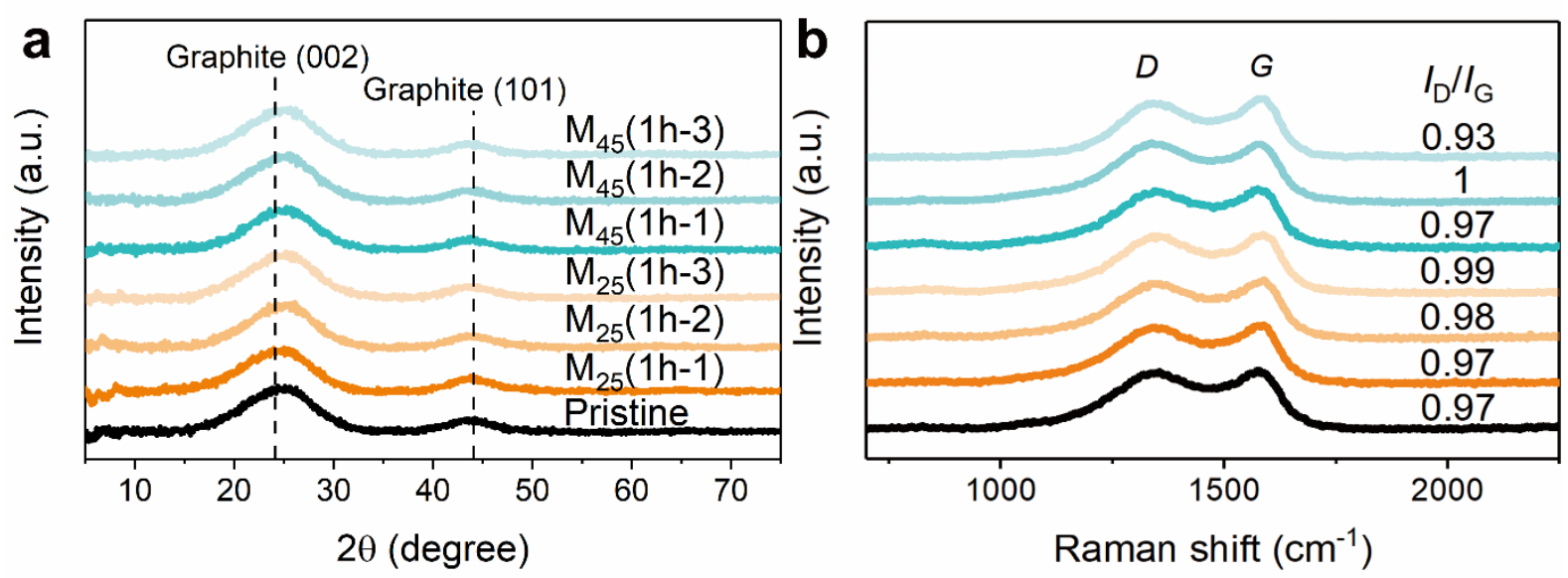

Fig. 3. (a) XRD patterns and (b) Raman spectra of $\mathrm{Fe}_{0.5}-\mathrm{NC}$ before and after wetting treatment at 25 and $45{ }^{\circ} \mathrm{C}$. The catalyst was wetted through mechanical agitation in water for $1 \mathrm{~h}$, and the number of treatments was varied.

\subsection{Physicochemical changes in the Fe-N-C catalyst after the wetting treatments}

We utilized various physicochemical characterization techniques to understand why the wetting of Fe-N-C catalysts with DI water decreases their ORR kinetics. The series of $\mathrm{M}_{25}(1 \mathrm{~h}-\mathrm{z})$ and $\mathrm{M}_{45}(1 \mathrm{~h}-\mathrm{z})$ samples $(\mathrm{z}=1,2$ and 3) was used for the characterizations due to the incremental changes in their ORR activity. The XRD patterns of the pristine and treated $\mathrm{Fe}_{0.5^{-}} \mathrm{NC}$ all showed two broad peaks at $c a .24^{\circ}$ and $44^{\circ}$, which corresponded to the (002) and (101) planes of graphite (Fig. 3a). The XRD signals of the catalysts did not exhibit significant changes, regardless of the wetting treatments applied. Similarly, their Raman spectra revealed almost identical D (at $c a .1350 \mathrm{~cm}^{-1}$ ) to $\mathrm{G}$ (at $c a .1590 \mathrm{~cm}^{-1}$ ) band intensity ratios $\left(I_{\mathrm{D}} / I_{\mathrm{G}}=c a\right.$. $0.96 \pm 0.04$ ) for all the samples (Fig. 3b). Therefore, the XRD and Raman spectra indicated 
that the modifications in the bulk carbon structure of the catalysts induced by simple wetting treatments were negligible. Other possible chemical changes were further studied with XPS (Fig. 4), which is more sensitive to surface changes than the two techniques above. However, the changes to the $\mathrm{N}_{1 \mathrm{~s}}$ and $\mathrm{O}_{1 \mathrm{~s}}$ signals after the wetting treatments were also insignificant (Figs. 4a-d), and the spectra of the various signals were nearly identical. The nitrogen and oxygen contents normalized by carbon content (i.e., $\mathrm{N} / \mathrm{C}$ and $\mathrm{O} / \mathrm{C}$ at\%) were within the range of $c a .6 .5 \pm 0.5$ at $\%$ for N/C and $6.5 \pm 0.6$ at\% for O/C (Fig. 4e).
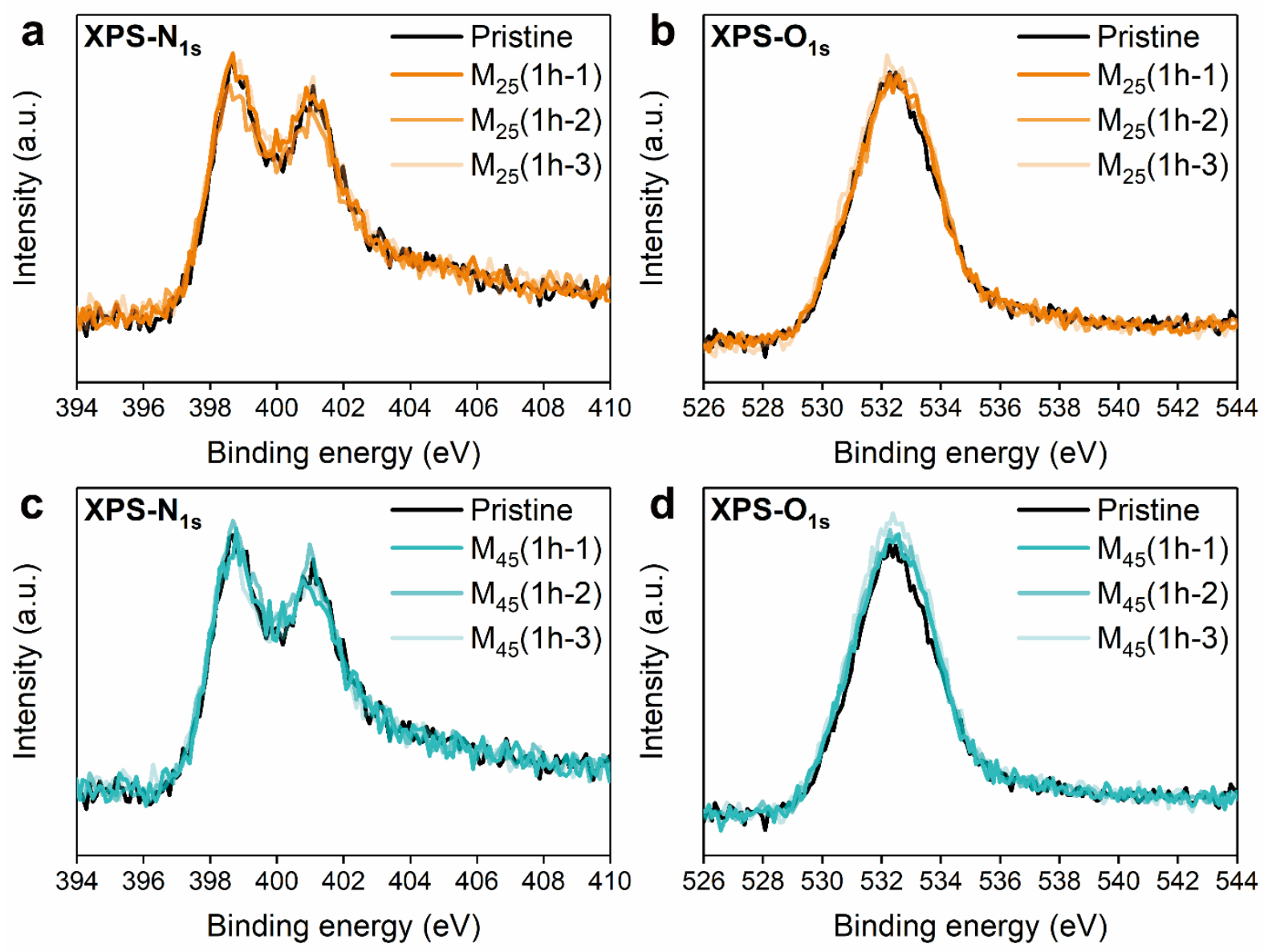

e

\begin{tabular}{cccccccc}
\hline & Pristine & $\mathrm{M}_{25}(1 \mathrm{~h}-1)$ & $\mathrm{M}_{25}(1 \mathrm{~h}-2)$ & $\mathrm{M}_{25}(1 \mathrm{~h}-3)$ & $\mathrm{M}_{45}(1 \mathrm{~h}-1)$ & $\mathrm{M}_{45}(1 \mathrm{~h}-2)$ & $\mathrm{M}_{45}(1 \mathrm{~h}-3)$ \\
\hline $\begin{array}{c}\mathrm{N} / \mathrm{C} \\
(\times 100, \%)\end{array}$ & 6.0 & 6.3 & 6.8 & 6.9 & 6.0 & 6.3 & 6.1 \\
$\begin{array}{c}\mathrm{O} / \mathrm{C} \\
(\times 100, \%)\end{array}$ & 5.9 & 6.1 & 6.4 & 6.2 & 6.2 & 7.1 & 6.8 \\
\hline
\end{tabular}

Fig. 4. High resolution XPS spectra of $\mathrm{Fe}_{0.5}$-NC before and after the treatments. Different numbers of wetting treatments were conducted at (a, b) 25 and (c, d) $45^{\circ} \mathrm{C}$. The catalyst was 
wetted through mechanical agitation in DI water for $1 \mathrm{~h}$. (e) $\mathrm{N}$ - and O-contents normalized by the C-contents calculated from the XPS- $\mathrm{N}_{1 \mathrm{~s}}$ and $-\mathrm{O}_{1 \mathrm{~s}}$ spectra.

While the changes in the chemical composition near the catalyst surface seem to be negligible and within the experimental error range of $c a .1$ at $\%$, we could not fully rule out marginal modifications of the surface chemistry of the Fe-N-C catalysts. For instance, we observed the activity recovery after electrochemical reduction of $\mathrm{M}_{45}(1 \mathrm{~h}-3)$ sample (showing the highest activity loss among the water-treated samples, Fig. S6). This activity recovery was previously reported on Fe-N-C catalysts with abundant surface-oxygen functional groups introduced by acidic $\mathrm{H}_{2} \mathrm{O}_{2}$ treatment [44]. Hence, we further measured the surface basicity of the treated $\mathrm{Fe}_{0.5}-\mathrm{NC}$ to clarify the changes in surface chemistry of $\mathrm{Fe}_{0.5}-\mathrm{NC}$ during wetting treatments. The surface basicity (i.e., $\Delta \mathrm{pH}_{\mathrm{f}}$ ) of $\mathrm{Fe}_{0.5}-\mathrm{NC}$, which has been suggested as a descriptor of their ORR kinetics [50], changed by $c a$. -0.5 after simple wetting treatment at 25 and $45^{\circ} \mathrm{C}$ (Fig. 5). In our previous study, significant ORR activity decrease was observed for $\mathrm{Fe}_{0.5}$-NC and also for a similarly prepared catalyst (with twice higher Fe content) after oxidative $\mathrm{H}_{2} \mathrm{O}_{2}$ treatment [44]. The performance drop was correlated to changes in the surface chemistry, namely, a substantial decrease in the basicity, i.e., a $\Delta \mathrm{pH}_{\mathrm{f}}$ of $c a .-1.5$ to -2.5 depending on the $\mathrm{H}_{2} \mathrm{O}_{2}$ treatment temperature. The much smaller changes in $\Delta \mathrm{pH}_{\mathrm{f}}$ observed in the present study imply that the wetting treatment in pure DI water led to much subtle modification of the surface of the Fe-N-C catalysts compared to the case of $\mathrm{H}_{2} \mathrm{O}_{2}$ treatment in acidic medium. It can thus be speculated that this small modification was difficult to be identified with XPS but was reflected in the change of $\Delta \mathrm{pH}_{\mathrm{f}}$ values for the $\mathrm{M}_{25}(1 \mathrm{~h}-\mathrm{z})$ and $\mathrm{M}_{45}(1 \mathrm{~h}-\mathrm{z})$ samples $(\mathrm{z}=1,2$ and 3), although the extent of the changes was not clearly differentiated. 


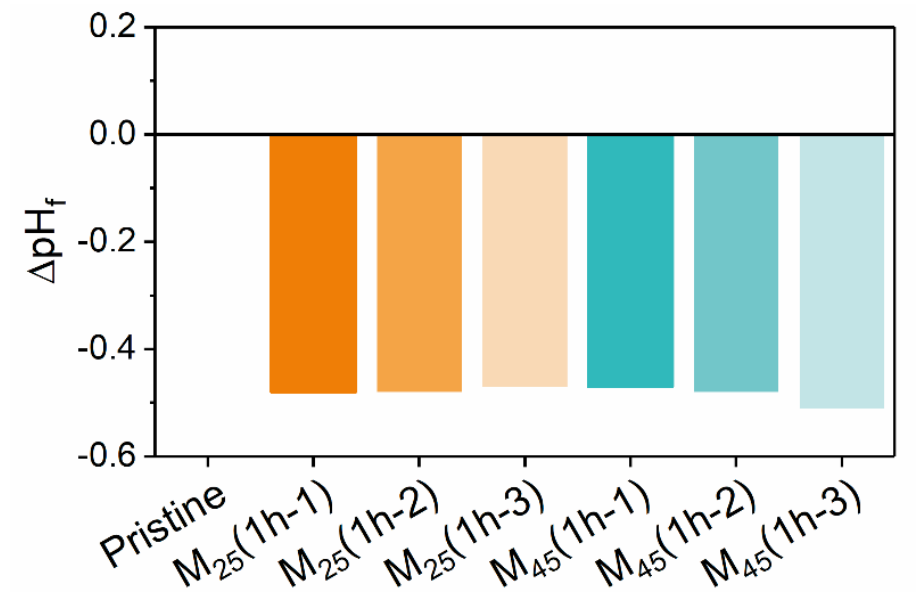

Fig. 5. Surface basicity changes $\left(\Delta \mathrm{pH}_{\mathrm{f}}\right)$ for $\mathrm{Fe}_{0.5}-\mathrm{NC}$ after mechanical agitation in DI water.

\subsection{Zeta potential measurements of the $\mathrm{Fe}-\mathrm{N}-\mathrm{C}$ catalyst after the wetting treatments}

To evaluate the surface modifications more precisely, the zeta potential of the Fe-N-C catalyst after the wetting treatments was also measured. Zeta potential $(\zeta)$ is the electric potential at the solid-liquid interface, and is strongly affected by the composition of the outermost surface of the solid material as well as by the $\mathrm{pH}$ of the solution [51-55]. Therefore, this method has been widely used to measure the surface functionality of carbonaceous materials, such as their acidity and basicity $[53,56,57]$. Figure 6 a shows the zeta potential of $\mathrm{Fe}_{0.5}$-NC before and after wetting treatment at 25 or $45{ }^{\circ} \mathrm{C}$ All the measurements were performed in a $0.1 \mathrm{M} \mathrm{HClO}_{4}$ solution. The pristine $\mathrm{Fe}_{0.5}-\mathrm{NC}$ exhibited a positive zeta potential value of $c a .3 \mathrm{mV}$. After the wetting and drying steps, however, all the treated catalysts exhibited values lower than zero. The zeta potential shifted to more negative values as either the treatment temperature or the number of treatments was increased. Therefore, this suggests that the wetting treatment induced a negative charge on the surface of the Fe-N-C catalysts. 

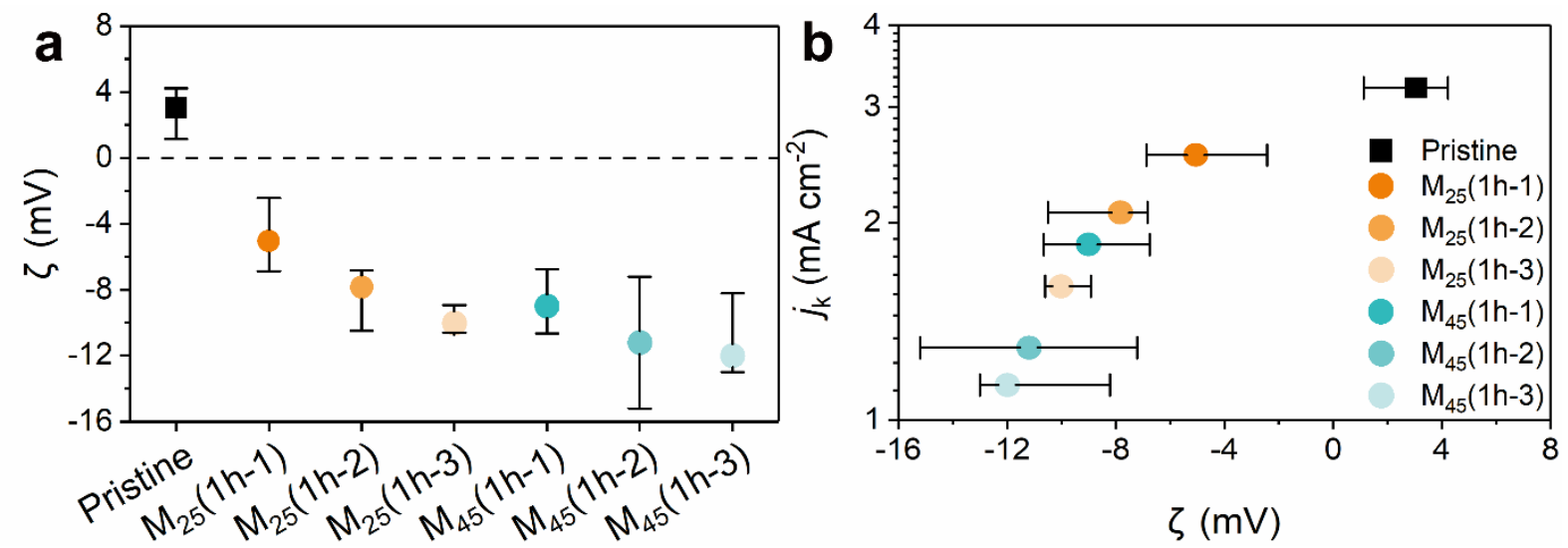

Fig. 6. (a) Zeta potential values of the pristine and water-treated $\mathrm{Fe}_{0.5}-\mathrm{NC}$ measured in $0.1 \mathrm{M}$ $\mathrm{HClO}_{4}$ solution and (b) the correlation between the ORR activity and zeta potential. The ORR activity was quantified using the kinetic current density $j_{\mathrm{k}}$ at $0.8 \mathrm{~V}_{\mathrm{RHE}}$.

In general, the introduction of oxygen-containing functional groups increases the acidity of carbon materials, while nitrogen functional groups increase their basicity [58-61]. However, the failure to observe modifications in the functional groups in the XPS- $\mathrm{N}_{1 \mathrm{~s}}$ and $\mathrm{O}_{1 \mathrm{~s}}$ spectra led us to surmise that the changes in the surface composition induced by the wetting treatments are very small. While the gradual modification of the surface charge after the different conditions applied during the wetting treatment could be clearly discerned in the zeta potential measurements, the variations (from 3 to $-12 \mathrm{mV}$ ) were smaller compared to that observed for carbon materials functionalized with acidic groups via oxidative treatments such as $\mathrm{HNO}_{3}$ treatments leading to $|\Delta \zeta|>20-30 \mathrm{mV}$, as measured in acidic pHs [62, 63]. However, this inconspicuous change in the surface basicity of the Fe-N-C catalysts resulted in non-negligible ORR activity losses (Fig. 2), and a positive correlation was observed between the ORR activity and the zeta potential at $\mathrm{pH}=1$ (Fig. 6b). This correlation suggested that the ORR activity of the active $\mathrm{FeN}_{\mathrm{x}} \mathrm{C}_{\mathrm{y}}$ moieties could be modulated by the basicity/acidity of the surrounding carbon surface, as has previously been reported for $\mathrm{NH}_{3}$ or $\mathrm{H}_{2} \mathrm{O}_{2}$-treated Fe-N-C materials, increasing the basicity and acidity, respectively [44, 50, 64, $65]$.

\section{Conclusions}

In conclusion, we showed that modifications of the surface occurring during wetting and subsequent drying process of Fe-N-C catalyst powders can lead to a non-negligible decrease 
in their ORR activity, depending on the sonication or mechanical agitation conditions. The conditions investigated here mimicked those typically employed during ink preparation for MEA fabrication. While ex situ XPS analyses did not reveal significant differences in the oxygen and nitrogen elemental content nor in the type of functional groups in $\mathrm{Fe}_{0.5}-\mathrm{NC}$, which typically determine the surface acido-basicity of carbon materials, the modifications of $\mathrm{Fe}_{0.5}-\mathrm{NC}$ surface after the treatments could be measured by $\Delta \mathrm{pH}_{\mathrm{f}}$ and more precisely by zeta potential analyses. The ORR activity drop was magnified with increasing temperature, duration and number of repetitions applied during the mechanical agitation or sonication treatments. Observed on Fe-N-C catalysts comprising $\mathrm{FeN}_{\mathrm{x}} \mathrm{C}_{\mathrm{y}}$ moieties but not on a commercial $\mathrm{Pt} / \mathrm{C}$ catalyst, we can surmise that the site-specific activity of $\mathrm{FeN}_{\mathrm{x}} \mathrm{C}_{\mathrm{y}}$ active moieties is strongly influenced by the surface chemistry of the carbonaceous support in which they are embedded. These findings imply that careful attentions should be paid to the methods and experimental conditions used for preparing $\mathrm{Fe}-\mathrm{N}-\mathrm{C}$ inks for $\mathrm{RDE}$ and/or PEMFC measurements, in order to avoid premature aging and ORR activity discrepancy from laboratory to laboratory for a same sample.

\section{Acknowledgments}

This research was supported by Technology Development Program to Solve Climate Changes through the National Research Foundation of Korea (NRF) funded by the Ministry of Science, ICT (2018M1A2A2063861). We thank Dr. Moulay-Tahar Sougrati for Mössbauer spectroscopy study. 


\section{References}

[1] H.A. Gasteiger, S.S. Kocha, B. Sompalli, F.T. Wagner, Appl. Catal. B Environ. 56 (2005) 9-35.

[2] D. Shin, K. Lee, N. Chang, Int. J. Hydrogen Energy 41 (2016) 1381-1390.

[3] Q. Dong, M.M. Mench, S. Cleghorn, U. Beuscher, J. Electrochem. Soc. 152 (2005) A2114-A2122.

[4] J.J. Baschuk, X. Li, J. Power Sources 86 (2000) 181-196.

[5] Y. Tabe, M. Nishino, H. Takamatsu, T. Chikahisa, J. Electrochem. Soc. 158 (2011) B1246B1254.

[6] T. Frey, M. Linardi, Electrochim. Acta. 50 (2004) 99-105.

[7] J. Wang, H. Wang, Int. J. Hydrogen Energy 37 (2012) 10881-10897.

[8] A. Kongkanand, M.F. Mathias, J. Phys. Chem. Lett. 7 (2016) 1127-1137.

[9] O. Okur, Ç. İyigün Karadağ, F.G. Boyacı San, E. Okumuş, G. Behmenyar, Energy 57 (2013) 574-580.

[10] S.M. Andersen, R. Dhiman, M.J. Larsen, E. Skou, Appl. Catal. B Environ. 172-173 (2015) 82-90.

[11] J. Xie, K.L. More, T.A. Zawodzinskl, W.H. Smith, J. Electrochem. Soc. 151 (2004) A1841-A1846.

[12] X. Leimin, L. Shijun, Y. Lijun, L. Zhenxing, Fuel Cells 9 (2009) 101-105.

[13] W. Wang, S. Chen, J. Li, W. Wang, Int. J. Hydrogen Energy 40 (2015) 4649-4658.

[14] K.S. Suslick, Science 247 (1990) 1439-1445.

[15] D.G. Shchukin, E. Skorb, V. Belova, H. Möhwald, Adv. Mater. 23 (2011) 1922-1934.

[16] M. Ashokkumar, Ultrason. Sonochem. 18 (2011) 864-872.

[17] H. Xu, B.W. Zeiger, K.S. Suslick, Chem. Soc. Rev. 42 (2013) 2555-2567.

[18] A. Sesis, M. Hodnett, G. Memoli, A.J. Wain, I. Jurewicz, A.B. Dalton, J.D. Carey, G. Hinds, J. Phys. Chem. B 117 (2013) 15141-15150.

[19] W. Huang, Y. Lin, S. Taylor, J. Gaillard, A.M. Rao, Y.-P. Sun, Nano Lett. 2 (2002) 231234.

[20] H. Xu, K.S. Suslick, J. Am. Chem. Soc. 133 (2011) 9148-9151.

[21] A. De Visscher, P. Van Eenoo, D. Drijvers, H. Van Langenhove, J. Phys. Chem. 100 (1996) 11636-11642.

[22] H. Destaillats, H.-M. Hung, M.R. Hoffmann, Environ. Sci. Technol. 34 (2000) 311-317.

[23] D.Q. Yang, J.F. Rochette, E. Sacher, J. Phys. Chem. B 109 (2005) 7788-7794. 
[24] S. Liang, G. Li, R. Tian, J. Mater. Sci. 51 (2016) 3513-3524.

[25] R. Bashyam, P. Zelenay, Nature 443 (2006) 63-66.

[26] L. Wu, Y. Nabae, S. Moriya, K. Matsubayashi, N.M. Islam, S. Kuroki, M.A. Kakimoto, J.I. Ozaki, S. Miyata, Chem. Commun. 46 (2010) 6377-6379.

[27] G. Wu, K.L. More, C.M. Johnston, P. Zelenay, Science 332 (2011) 443-447.

[28] F. Jaouen, E. Proietti, M. Lefèvre, R. Chenitz, J.P. Dodelet, G. Wu, H.T. Chung, C.M. Johnston, P. Zelenay, Energy Environ. Sci. 4 (2011) 114-130.

[29] E. Proietti, F. Jaouen, M. Lefèvre, N. Larouche, J. Tian, J. Herranz, J.P. Dodelet, Nat. Commun. 2 (2011) 71-74.

[30] F. Jaouen, V. Goellner, M. Lefèvre, J. Herranz, E. Proietti, J.P. Dodelet, Electrochim. Acta. 87 (2013) 619-628.

[31] G. Wu, P. Zelenay, Acc. Chem. Res. 46 (2013) 1878-1889.

[32] N. Ramaswamy, U. Tylus, Q. Jia, S. Mukerjee, J. Am. Chem. Soc. 135 (2013) 1544315449.

[33] J. Tian, A. Morozan, M.T. Sougrati, M. Lefèvre, R. Chenitz, J.-P. Dodelet, D. Jones, F. Jaouen, Angew. Chem. Int. Ed. 52 (2013) 6867-6870.

[34] U.I. Kramm, M. Lefèvre, N. Larouche, D. Schmeisser, J.-P. Dodelet, J. Am. Chem. Soc. 136 (2014) 978-985.

[35] J. Masa, W. Xia, M. Muhler, W. Schuhmann, Angew. Chem. Int. Ed. 54 (2015) 1010210120.

[36] J. Li, S. Ghoshal, W. Liang, M.-T. Sougrati, F. Jaouen, B. Halevi, S. McKinney, G. McCool, C. Ma, X. Yuan, Z.-F. Ma, S. Mukerjee, Q. Jia, Energy Environ. Sci. 9 (2016) 24182432.

[37] U.I. Kramm, I. Herrmann-Geppert, J. Behrends, K. Lips, S. Fiechter, P. Bogdanoff, J. Am. Chem. Soc. 138 (2016) 635-640.

[38] J.A. Varnell, E.C.M. Tse, C.E. Schulz, T.T. Fister, R.T. Haasch, J. Timoshenko, A.I. Frenkel, A.A. Gewirth, Nat. Commun. 7 (2016) 12582.

[39] Y. Chen, S. Ji, Y. Wang, J. Dong, W. Chen, Z. Li, R. Shen, L. Zheng, Z. Zhuang, D. Wang, Y. Li, Angew. Chem. Int. Ed. 56 (2017) 6937-6941.

[40] H.T. Chung, D.A. Cullen, D. Higgins, B.T. Sneed, E.F. Holby, K.L. More, P. Zelenay, Science 357 (2017) 479-484.

[41] C.H. Choi, C. Baldizzone, J.-P. Grote, A.K. Schuppert, F. Jaouen, K.J.J. Mayrhofer, Angew. Chem. Int. Ed. 54 (2015) 12753-12757. 
[42] C.H. Choi, C. Baldizzone, G. Polymeros, E. Pizzutilo, O. Kasian, A.K. Schuppert, N. Ranjbar Sahraie, M.T. Sougrati, K.J.J. Mayrhofer, F. Jaouen, ACS Catal. 6 (2016) 3136-3146. [43] C.H. Choi, W.S. Choi, O. Kasian, A.K. Mechler, M.T. Sougrati, S. Brüller, K. Strickland, Q. Jia, S. Mukerjee, K.J.J. Mayrhofer, F. Jaouen, Angew. Chem. Int. Ed. 56 (2017) 8809-8812. [44] C.H. Choi, H.-K. Lim, M.W. Chung, G. Chon, N. Ranjbar Sahraie, A. Altin, M.-T. Sougrati, L. Stievano, H.S. Oh, E.S. Park, F. Luo, P. Strasser, G. Dražić, K.J.J. Mayrhofer, H. Kim, F. Jaouen, Energy Environ. Sci. 11 (2018) 3176-3182.

[45] H.-L. Guo, X.-F. Wang, Q.-Y. Qian, F.-B. Wang, X.-H. Xia, ACS Nano 3 (2009) 26532659.

[46] K. Makino, M.M. Mossoba, P. Riesz, J. Am. Chem. Soc. 104 (1982) 3537-3539.

[47] S. Sochard, A.M. Wilhelm, H. Delmas, Ultrason. Sonochem. 4 (1997) 77-84.

[48] Y. Wang, D. Zhao, H. Ji, G. Liu, C. Chen, W. Ma, H. Zhu, J. Zhao, J. Phys. Chem. C 114 (2010) 17728-17733.

[49] K. Kerboua, O. Hamdaoui, Ultrason. Sonochem. 41 (2018) 449-457.

[50] A. Zitolo, V. Goellner, V. Armel, M.-T. Sougrati, T. Mineva, L. Stievano, E. Fonda, F. Jaouen, Nat. Mater. 14 (2015) 937-942.

[51] J.-J. Shyue, M.R. De Guire, T. Nakanishi, Y. Masuda, K. Koumoto, C.N. Sukenik, Langmuir 20 (2004) 8693-8698.

[52] K.-S. Khoo, E.J. Teh, Y.-K. Leong, B.C. Ong, Langmuir 25 (2009) 3418-3424.

[53] B. Konkena, S. Vasudevan, J. Phys. Chem. Lett. 3 (2012) 867-872.

[54] C. Revathi, K. Rajavel, M. Saranya, R.T. Rajendra Kumar, J. Electrochem. Soc. 163 (2016) B627-B632.

[55] E. Skwarek, Y. Bolbukh, V. Tertykh, W. Janusz, Nanoscale Res. Lett. 11 (2016) 166.

[56] L. Vaisman, G. Marom, H.D. Wagner, Adv. Funct. Mater. 16 (2006) 357-363.

[57] S. Rosenzweig, G.A. Sorial, E. Sahle-Demessie, J. Mack, Chemosphere 90 (2013) 395402.

[58] J. Herranz, F. Jaouen, M. Lefèvre, U.I. Kramm, E. Proietti, J.-P. Dodelet, P. Bogdanoff, S. Fiechter, I. Abs-Wurmbach, P. Bertrand, T.M. Arruda, S. Mukerjee, J. Phys. Chem. C 115 (2011) 16087-16097.

[59] U.I. Kramm, J. Herranz, N. Larouche, T.M. Arruda, M. Lefèvre, F. Jaouen, P. Bogdanoff, S. Fiechter, I. Abs-Wurmbach, S. Mukerjee, J.-P. Dodelet, Phys. Chem. Chem. Phys. 14 (2012) 11673-11688.

[60] J.A. Menéndez, J. Phillips, B. Xia, L.R. Radovic, Langmuir 12 (1996) 4404-4410. 
[61] T.A. Saleh, Appl. Surf. Sci. 257 (2011) 7746-7751.

[62] P. Chingombe, B. Saha, R.J. Wakeman, Carbon 43 (2005) 3132-3143.

[63] E. Heister, C. Lamprecht, V. Neves, C. Tîlmaciu, L. Datas, E. Flahaut, B. Soula, P. Hinterdorfer, H.M. Coley, S.R.P. Silva, J. McFadden, ACS Nano 4 (2010) 2615-2626.

[64] F. Jaouen, F. Charreteur, J.P. Dodelet, J. Electrochem. Soc. 153 (2006) A689-A698.

[65] V. Goellner, V. Armel, A. Zitolo, E. Fonda, F. Jaouen, J. Electrochem. Soc. 162 (2015) H403-H414. 